\title{
ССЫЛЬНЫЕ ПОЛЯКИ В ВОЛОГОДСКОЙ ГУБЕРНИИ В 19 ВЕКЕ: РОССИЙСКАЯ ИСТОРИОГРАФИЯ И ПЕРСПЕКТИВЫ ИССЛЕДОВАНИЯ
}

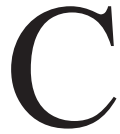

овременный регион - Вологодская область и Вологодская губерния, существовавшая в 1796-1917 гг. довольно сильно отличаются географически. Границы Вологодской области установлены в 1936 году; во времена, нас интересующие, территория Вологодской губернии распространялась в основном на северо-восток от Вологды. В нее входили частично территории современной Архангельской области и республики Коми. Губерния состояла из десяти уездов, центрами которых были уездные города. А город Усть-Сысольск - наиболее удаленный уездный город Вологодской губернии - сейчас столица республики Коми - Сыктывкар. Западная часть нынешней Вологодской области в XIX веке в основном относилась к Новгородской губернии.

Вологодская губерния представляла собой довольной большой регион, традиционно использовавшийся в XIX - начале XX века царским правительством как место политической ссылки. Обычно это объясняется неразвитостью путей сообщения, социальной жизни в городах, удаленностью уездных центров. С точки зрения царских властей, это создавало хорошие условия для изоляции ссыльных в губернии, получившей название термин «подстоличная Сибирь».

Наряду с Вятской и Новгородской, Вологодская губерния относилась к так называемым “внутренним губерниям", которые значительно меньше использовались для ссылки участников восстаний в Царстве Польском в 19 веке по сравнению с сибирскими регионами.

Тем не менее определенное количество поляков оказалось на территории Вологодской губернии в 1830-1860-е годы.

Изучение особенностей политической ссылки участников восстаний в Царстве Польском началось еще в XIX веке. Первые дореволюционные и послереволюционные публикации были немногочисленны носили эпизодический и описательный характер. Советская историография 70-80-х годов 
делала главным предметом исследований польско-российские революционные связи ${ }^{1}$.

Современная российская историография о польских ссыльных 19 века насчитывает десятки публикаций. Российские историки весьма подробно изучили важнейшие аспекты ссылки поляков в сибирские и уральские губернии. Можно назвать таких авторов как Е.П. Береговая ${ }^{2}$, А.С. Жарова ${ }^{3}$, В.В. Латыпова ${ }^{4}$, С.А. Мулина ${ }^{5}$ Их публикации и диссертации посвящены изучению ссыльных участников польских восстаний в западной и южной Сибири, на южном Урале. Есть интересные работы, касающиеся этой темы, по Забайкальскому и Пермскому краю ${ }^{6}$ и Северному Кавказу ${ }^{7}$ Последняя работа относится к группе работ, в которых изучалась более широкая тема польской диаспоры в отдельных регионах Российской империи и ссыльные поляки составляли лишь часть исследуемого вопроса ${ }^{8}$.

Отметим, что все эти работы выполнены в основном в последние пятнадцать лет. Таким образом, во многом исправлен отмечавшийся недостаток советской исторической науки, которая, изучая в целом борьбу с царским режимом и ее последствия, упускала из виду региональные аспекты ссылки.

Имеются и многим известны несколько обобщающих работ по польско-российским отношениям и взаимному влиянию в 19 веке, в которых так или иначе рассматривается тема польской ссылки'.

\footnotetext{
${ }^{1}$ См., например: Русско-польские революиионные связи: В 2-х т. Т. 2. Восстание 1863 г.: Материальи и документыл. М.: Изд-во АН СССР, 1963.

2 Береговая Е.П., Польская политическая ссылка в Енисейской губернии во второй половине $X I X$ - начале $X X$ вв.: диссертация... кандидата исторических наук, Красноярск 2007.

3 Жарова А.С., Возникновение и развитие польской общины в Курганском уезде Тобольской губернии во второй половине XIX - начале XX в.: автореферат дис... кандидата исторических наук, Челябинск 2015.

4 Латыпова В.В., Поляки на Южном Урале (XVII - начало XX вв.): автореферат дис... кандидата исторических наук, Санкт-Петербург 1996.

${ }^{5}$ Мулина С.А. Мигранты поневоле: адаптация ссыльных участников польского восстания 1863 года в Западной Сибири; отв. ред. проф. А.В. Ремнев. Санкт-Петербург: Алетейя 2012, 199 с.

${ }^{6}$ См.: Гапоненко В.В., Семенов Е.В., Польские политические ссыльные в хозяйственной и культурной жизни Забайкалья в первой половине XIX в., Улан-Удэ 2006; Терехин А.А., Ссылка в Пермской губернии в XIX в. Диссертация на соискание ученой степени кандидата исторических наук. Пермь 2003.

${ }^{7}$ Цифанова И.В., Польские переселенцы на Северном Кавказе в ХІХ веке: Особенности nроцесса адаптащии: автореферат дис... кандидата исторических наук, Ставрополь 2005, 25 с.

${ }^{8}$ См. также: Пичугина В.В., Польская интеллигенция в общественно-политической жизни Поволжья и Приуралья (в XIX веке): автореферат дисс.... канд. ист. Наук, Казань 2000; Селицкий А. И., Поляки на Кубани: Исторические очерки, Издание Кубан. гос. ун-та. Краснодар 2008.

${ }^{9}$ См., например: Польская политическая ссылка в России XIX-XX веков региональные аспекты / Сборник статей, Казань 1998; Поляки в России: XVII-XX вв., Краснодар 2003; Островский Л.К., Поляки в Западной Сибири в конще XIX-первой четверти XX века: диссертация... доктора исторических наук, Новосибирск 2014.
} 
В целом можно констатировать, что сибирская ссылка изучена уже достаточно неплохо, что, конечно, обусловлено ее значительной массовостью по сравнению с европейскими регионами России.

Конечно, европейская часть России не остались без интереса местных историков. Можно сказать, что особенности ссылки участников восстаний в Царстве Польском в соседних с Вологодской губернией регионах в известной степени изучены.

Так, ссылка в соседней с Вологодской Вятской губернии достаточно подробно проанализирована в частности, в диссертационном исследовании Л.Г. Подлевских, который изучил особенности ссылки участников январского восстания в Вятскую губернию в $1860-1880-$ х гг. ${ }^{10}$ Автор подробно анализирует организационно-правовые аспекты ссылки участников восстания по законам Российской империи, группы ссыльных в зависимости от вида ссылки (надзор полиции и арестантские роты), динамику и т.д. Особенностью исследования является также изучение взаимоотношений ссыльных и местного населения и предложенный автором анализ коммуникативного пространства польских ссыльных второй половины XIX века.

Региональные аспекты организации и особенностей политической ссылки участников восстания 1863 года имеет своего исследователя ${ }^{11}$ лежащая к северу от Вологодской Архангельская область. Л.П. Кононова в своей работе также пишет о правовых аспектах ссылки, ее разновидностях, особенностях этапирования и содержания ссыльных, их вкладе в местную культурную жизнь. Изучена самая многочисленная арестантская рота того времени, которая размещалась в Архангельске, установлена численность польских ссыльных.

Новгородская губерния - еще более близкий к Польше регион, лежащий между Москвой и Санкт-Петербургом. Ссыльные повстанцы попадали и туда. Небольшая группа ссыльных участников Январского восстания, отбывавших ссылку в Новгородской губернии, и отдельные исторические фигуры изучалась местными и польскими историками. Общей объемной монографической работы работы по этой теме пока нет, но в 2013 году был издан сборник материалов научной конференции, которая прошла в Великом Новгороде и была приурочена к 150-летию Январского восстания ${ }^{12}$.

${ }^{10}$ Подлевских Л.Г., Польская политическая ссылка в Российской провинции в 1860-начале 1880-х г2.: На материалах Вятской губернии: автореферат дис... кандидата исторических наук, Ижевск 2004, 24 с.

${ }^{11}$ Кононова Л.П., Ссылка участников польского восстания 1863-1864 годов: По материалам Архангельской губернии: автореферат дис... кандидата исторических наук, Архангельск 2004.

${ }^{12}$ К 150-летию Январского восстания в Польше: Польские ссыльные в Новгородской губернии / отв.редактор Б.Н. Ковалев, Великий Новгород 2013, с. 92-97. 
Авторы публикаций дают общую характеристику жизни ссыльных в регионе, анализируют историю отдельных ссыльных, таких, как, например, Адам Гуровский.

В контексте темы настоящей статьи этот сборник интересен по нескольким причинам: Новгородская губерния располагается по соседству с Вологодской и весьма близка по природным и социально экономическим условиям; многие территории и города тогдашней Новгородской губернии теперь входят в современную Вологодскую область. Среди публикаций сборника одна посвящена сравнительному анализу положения ссыльных в Вологодской и Новгородской губернии, содержит интересные факты и обобщения, поэтому к ней мы вернемся чуть ниже ${ }^{13}$. Вторая часть публикации содержит архивные документы региона, касающиеся ссыльных и несколько обзорных статей ${ }^{14}$.

Имея представление о степени изученности проблемы в соседних регионах, обратимся к более подробному анализу имеющихся региональных публикаций по теме.

Во-первых, следует сказать о двух статьях, опубликованных в начале 2000-х годов, принадлежащих авторству М.Ш. Бонфельда. Это известный вологодский искусствовед и музыкальный педагог. Видимо, его профессия обусловила своеобразие рассмотрения вопроса о польских ссыльных в Вологде.

Первая публикация М.Ш. Бонфельда посвящена анализу польской культурной среды в Вологде в середине XIX века ${ }^{15}$. Автор показывает контекст - состояние Вологды 1830-х гг. как губернского центра (количество жителей - 16 000, каменных домов, библиотек, церквей, состояние тротуаров и т.п.), приводит биографические данные ссыльных из Царства Польского, указывает на барьеры, ограничивающие общение поляков с местными жителями. В качестве исключения приведены истории ссыльных Буховицкого и Дроздовского, которым удалось более успешно встроиться в провинциальное российское общество.

В своей второй статье «Странники поневоле» ${ }^{16}$ М.Ш. Бонфельд развивает эту тему и более подробно рассматривает (в первую очередь, на основе реги-

${ }_{13}$ Алекссева М.А., Сравнительный анализ положения польских ссыльных в Вологодской и Новгородской губерниях // К 150-летию Январского восстания в Польше..., Великий Новгород 2013, с. 74-83.

14 Участники Январского восстания в ссылке в Новгородской губернии: сборник документов, Великий Новгород 2015.

${ }^{15}$ Бонфельд М.Ш., Польская культурная среда в Вологде середины ХІХ века // Поляки и русские: взаимопонимание и взаимонепонимание / Рос. гос. гуманитар. ун-т, Рос. акад. наук, Ин-т славяноведения, Польский ин-т при посольстве РП в Москве, 2000, с. 110-119.

${ }^{16}$ Бонфельд М.Ш., Странники поневоле // Вологда: Краеведческий альманах. Вып. 4. - Вологда: „Легия” 2003, с. 63-80. 
ональных архивных материалов) судьбы поляков, сосланных в Вологодскую губернию в 1830-е гг. и выделяет две группы: во-первых, это одиннадцать высокопоставленных офицеров - участников ноябрьского восстания (Осип Морозинский, Круковецкий, Ксаверий Неселовский, Редель и другие). Автором даны краткие биографические характеристики офицеров и генералов и их ссыльная судьба. Все ссыльные, видимо, были возвращены на родину к середине 1830-х гг.

М.Ш. Бонфельд, как искусствовед, обращает особое внимание на творческие аспекты деятельности ссыльных и фигуры, как-то связанные с творчеством. Так, он рассказывает о переписке Франтишека Моравского, бригадного генерала и литературного деятеля, вернувшегося из вологодской ссылки в 1833 году. Оно художественно описывал в письмах свое пребывание в Вологде, восхищение народной культурой.

Также в статье описана вторая волна польских политических ссыльных, связанная с репрессиями в отношении причастных к делу Шимона Конарского. Это были второстепенные участники дела, получившие гораздо более серьезные наказания, чем участники Ноябрьского восстания. В 1840 году их было около десяти человек.

М.Ш. Бонфельд объясняет, почему активного участия эти ссыльные не сыграли. Во-первых, маленький город облегчал надзор полиции и ограничения в общении. Во-вторых, само провинциальное дворянство было слишком немногочисленно и тесно связано между собой, с трудом принимало новых людей.

Интересный пример ссыльного, не связанного с восстанием и делом Конарского также приведен в публикации Бонфельда. Это польский дворянин Антон Буховицкий, который «за необдуманные речи и неприличные выражения в связи с событиями во Франции был сослан в Вологодскую губернию, город Кадников и подвергнут надзору полиции» ${ }^{17}$. Буховицкий пытался зарабатывать литературной деятельностью в ссылке, но, видимо, безуспешно.

Другим, более успешным примером культурного влияния ссыльных на жизнь вологодской провинции была история ссыльного Станислава Дроздовского, уроженца Минской губернии, также участника дела Конарского. Удивительно, что получив через три года смягчение и возможность уехать ближе к родным местам, Дроздовский остался в Вологде, так как именно здесь начал работать в качестве частного (семейного) учителя музыки, женился, и даже пригласил в Вологду своих братьев. После 1860 года сведений о Дроздовском в архивных документах полиции уже нет.

17 Бонфельд М.Ш., Странники поневоле // Вологда: Краеведческий альманах. Вып. 4. - Вологда: „Легия” 2003, с. 63-80. 
Кроме того, М.Ш. Бонфельд останавливается подробнее на фигурах Северина и Эдуарда Ромера, Медарда Конча, которые были оставлены в Вологодской губернии на полтора десятка лет в силу особой политической неблагонадежности, по указанию виленского военного губернатора. Действительно, Эдуард Ромер пытался создать некое тайное сообщество ссыльных, за что был отправлен дальше, в Великий Устюг. Его ссыльная история через переписку подробно рассмотрена в публикации.

Архивные данные, использованные М.Ш. Бонфельдом (документы полицейского надзора, канцелярии губернатора и т.п.), позволяют проследить: основные биографические данные, особенности быта (жилье, питание), отношения с соседями, круг чтения, официальную переписку ссыльных с властями.

В статье вологодского искусствоведа М.Е. Даен показано влияние ссыльных поляков на провинциальную живопись и социальную верхушку губернии ${ }^{18}$.

Более массовая ссылка участников Январского восстания изучалась вологодским историком Н.И. Голиковой, две статьи которой посвящены следующему периоду в польской истории вологодской ссылки, в основном, 1863-1874 гг.

В первой публикации автор приводит некоторые данные общего характеpa: воспоминания вологжан о польских ссыльных, описание архивных фондов в государственном архиве Вологодской области, содержащих данные по теме (фонды Вологодского губернского правления, канцелярии губернатора, полицмейстера и полицейского управления, уездных полицейских управлений Вологды и Тотьмы $)^{19}$.

Н.И. Голикова показывает трудности в работе с архивными материалами (в частности, разночтения и ошибки в написании фамилий ссыльных), данные о социальном составе 80 ссыльных и месте их предыдущего проживания (в основном, так называемые Западные губернии, 43\% дворяне). Из статьи можно узнать информацию о размещении ссыльных по разным уездным центрам, их материальном обеспечении (15 копеек в день кормовых, 1 p. 50 коп. в месяц на жилье). В связи с недостатком материального обеспечения ссыльные вынуждены были как-то работать (писцами, торговцами, цирюльниками), хотя на некоторые виды деятельности, которую могли вести образованные люди, был наложен запрет (в первую очередь, преподавание).

18 Даен М.Е., О польской ориентации в вологодском искусстве ХІХ века // Археография и источниковедение истории Европейского Севера РСФСР.Ч.2, 1989, с. 85.

${ }_{19}$ См.: Голикова Н.И., Польские ссыльные в Вологодской губернии в 60-е годы ХІХ века // Историческое краеведение и архивы. - Вологда. - Вып. 10, 2004, с. 118-131. 
Вторая статья Н.И. Голиковой углубляет и развивает тему ${ }^{20}$. Автор описывает контекст - природно-географические особенности Вологодской губернии XIX века, разницу между ее десятью уездами, организационно-правовые аспекты полицейского надзора за политическими ссыльными в губернии (в частности, нехватка сотрудников, особенности материального обеспечения). Далее автор анализирует архивные данные о 80 участниках Январского восстания в семи (из десяти) уездах Вологодской губернии, прибывших в губернию в 1863-1864 гг. Отдельно упомянуты несколько человек, прибывших позже, однако также в связи с восстанием (Аполлон Коженевский с семьей - отец Д.Конрада, Станислав Щука). Помимо них, автор указывает еще на дополнительные группы ссыльных. Первая прибыла в 1865 году, это были вернувшиеся из-за границы участники восстания. Вторая, прибывшая в 1871 г. в Великий Устюг, была из Сибири, из более тяжелых условий (11 человек).

Обобщенные статистические данные, сделанные на основе архивных данных, приведены в приложении к публикации в виде таблиц и диаграмм: о месте происхождения, о социальном происхождении ссыльных, степени политической активности или вовлеченности в восстание $(24 \%$ - «находились в отрядах», 24\% - «активное косвенное участие», «пассивное косвенное участие», «политическая неблагонадежность» и т.д.), возрасту (большая часть - люди в возрасте от 21 до 30 лет), территориальному распределению (37 человек в самом удаленном городе - Усть-Сысольске, 15 - Великий Устюг и 10 - Сольвычегодск), видам надзора (гласный или секретный).

Приведены интересные подробности о деле Адама Подгурского, который был определен в Сольвычегодск по прибытии из-за границы, как участник восстания, и как оскорблявший императора. Он пытался бежать из Сольвычегодска, но был задержан в Архангельске и возвращен под усиленный надзор.

Историк из Великого Новгорода Е.А. Макарова сравнивает положение польских ссыльных в Вологодской и Новгородской губернии. В обоих регионах ссыльные помещались чаще в удаленные города, в Новгородской области ими были Кириллов и Белозерск (сейчас это территория Вологодской области) $)^{21}$. Автор сравнивает материальное положение ссыльных, причем также с данными по сибирским регионам в контексте цен на продукты,

${ }^{20}$ Голикова Н.И., Участники польского восстания 1863-1864 г2. в вологодской ссылке // Власть и общество на Европейском Севере России: исторический опыт и современность / Федер. служба исполнения наказаний, Вологод. ин-т права и экономики, Вологод. гос. пед. ун-т, Сев. отд-ние Центра воен. истории России ИРИ РАН, Совет кафедр и секций истории вузов Вологод. обл. Вологда 2010, с. 132-136.

${ }^{21}$ Макарова Е.А., Сравнительный анализ польских ссыльных в Вологодской и Новгородской губернии // К 150-летию Январского восстания в Польше: Польские ссыльные в Новгородской губернии / отв.редактор Б.Н. Ковалев, Великий Новгород 2013, с. 92-97. 
силу надзора (так, частные уроки, которые давали ссыльные, в Новгородской губернии ограничивались жестче), приводит данные о католиках в Вологодской губернии, количество которых к 1914 году выросло почти втрое с 1861 года. Приведены и частные истории, например, история Анны Чаплицкой, которая была ссыльной в Тотьме и вышла замуж за П.Л. Лаврова, народника и философа.

Большая часть сосланных в Вологодскую губернию оказалась в наиболее удаленных городах, таких, как Усть-Сысольск. Статья доктора филологических наук Г.И. Тираспольского, посвященную пребыванию в Усть-Сысольске (нынешнем Сыктывкаре) ссыльных поляков в 1867 году22.

Автор указывает общее число ссыльных участников восстания, а именно 45 человек, из которых часть размещалась в пригороде, перечисляет некоторые подробности, касающиеся конкретных людей (например, ксендза Юзефа Бужиньского), подробно описывает город с населением 3400 человек, напоминающий огромную деревню, где только деревянные дома и нет водопровода, иные условия содержания ссыльных.

Поляки, появившись в Усть-Сысольске, стали заметным явлением, пишет Г.И. Тираспольский. Образованные люди другой культуры привлекали внимание в клубе, библиотеке, на вечеринках. Их вспоминали, как прекрасных собеседников, танцоров, музыкантов, людей разносторонних. Среди ссыльных в Усть-Сысольске были Станислав Кракув, переводивший на польский роман «Что делать?», Винсент Журавки, литератор, оставивший, в том числе, интересные краеведческие описания северных территорий. Г.И. Тираспольский приводит большие выдержки из его очерка и переписки.

Ссыльные старались подобрать себе хорошее жилье, в частности, несколько человек снимали комнаты с питанием в доме Казариновой. Показано взаимодействие с местными жителями. В частности, несколько человек приобрели знания польского языка и литературы, например, И.В.Куратов, языковед-самоучка, основатель литературы на языке коми, живший с поляками в одном доме ${ }^{23}$.

Таким образом, можно сделать определенные выводы на основе имеющихся публикаций:

1. Вологодская губерния последовательно становилась в XIX веке местом ссылки для нескольких групп жителей Царства Польского и т.н. Западных губерний: 1830-е годы - 11 генералов и офицеров, участников Ноябрьского восстания; 1840 год - около десяти причастных к делу Шимона Конарского;

22 Тираспольский Г.И., Ссыльные поляки в Усть-Сысольске 1860-х г2. // Родники Пармы. Республиканский научно-краеведческий альманах. Вып. 5, Сыктывкар 2000, с. 4-13.

${ }_{23}$ Тираспольский Г.И., Ссыльные поляки в Усть-Сысольске 1860-х г2. // Родники Пармы. Республиканский научно-краеведческий альманах. Вып. 5, Сыктывкар 2000, с. 10. 
1863-1864 - е годы - более 80 участников Январского восстания; 1871 - 11 человек, перемещенных из Сибири в связи со смягчением условий ссылки. Кроме того, были отдельные лица, сосланные вне прямой связи с восстанием, за политическую неблагонадежность.

2. В имеющихся исследованиях обобщены данные о социальном происхождении значительной части ссыльных участников восстания 1863 года, их возрасте, месте жительства до ссылки, видам надзора, степени вовлеченности в восстание и некоторые другие. Собраны и опубликованы некоторые биографические данных о ссыльных, данные об их взаимодействии с местным населением и влиянии на общество.

3. Исходными источниками о польских ссыльных выступают в первую очередь архивные документы Государственного архива Вологодской области, кроме того, часть материалов содержится в архивах республики Коми, Архангельской области. Это в основном документы государственных учреждений губернии, полицейского ведомства, содержащие списки ссыльных, общие биографические данные о них, официальная переписка, материалы полицейского надзора, различные письменные документы, оставленные ссыльными и изъятые полицией. Источниками о ссыльных могут выступать воспоминания местных жителей, самих ссыльных.

В целом, несмотря на наличие нескольких важных публикаций, можно сделать вывод, что Вологодская губерния пока не получила своего объемного комплексного исследования оп польских ссыльных 19 века. В связи с этим некоторые вопросы остаются нераскрытыми или малоизученными.

Можно предложить об актуальности следующих взаимосвязанных направлений исследований по этой теме:

1. Детальный анализ данных о ссыльных, размещенных в различных городах губернии, уточнение их количества (в публикациях есть противоречия), сроков пребывания, места жительства в ссылке, биографических данных. Результатом может стать, в частности, составление подробного списка всех польских ссыльных с разделением по группам, исходя из географического положения.

2. Подробное изучение материалов полицейского надзора, которые имеются по каждому ссыльному. Этот материал содержит интересные фактические данные, в том числе и об особенностях повседневной жизни региона.

3. Обработка и публикация официальных архивных источников по теме. Для этого необходима работа в нескольких архивных учреждениях. Источники можно разделить на группы по видам государственных органов, 
составлявших документы: губернское правление, полицейские органы губернии и уездов и т.п.

4. Поиск, изучение и публикация писем и иных частных документов, исходивших от ссыльных. Частично они находятся в российских архивах, но возможно их обнаружения в Польше, в частных архивах и т.п.

5. Исследование и обобщение воспоминаний: опубликованные воспоминания местных жителей, которые взаимодействовали с польскими ссыльными (они публиковались в российской периодике 19 века, имеются в краеведческой литературе); воспоминания ссыльных, в том числе из других регионов, а также родственников ссыльных, находившихся в Вологодской губернии.

6. Интересным может стать изучение данных о ссыльных в совокупности с данными об их предыдущей жизни, участии в важных событиях, о последующей судьбе. Интерес представляет также судьба ссыльных, оставшихся на территории региона после получения возможности вернуться на родину.

7. За пределами статьи остается также история поляков - участников армии Наполеона, которые оказались на территории Вологодской губернии после 1813 года. Это отдельная тема также заслуживает научного интереса.

Anton Liutynski

\section{POLISH DEPORTATION IN THE VOLOGDA PROVINCE (VOLOGODSKAYA GUBERNIA) IN THE $19^{\text {TH }}$ CENTURY: RUSSIAN HISTORIOGRAPHY AND RESEARCH PERSPECTIVES}

$\mathrm{V}$ ologda Province, the region of the Russian Empire (1796-1917), was used in the XIX - early $\mathrm{XX}$ century by the tsarist government as a place of political exile. A certain number of participants in the revolutionary movement in the Kingdom of Poland in the $19^{\text {th }}$ century was exiled to the province.

The Russian historiography of the Polish exile mainly refers to the Siberian regions, where exiles were much larger. There are interesting and detailed studies of Polish exiles in the neighboring Arkhangelsk, Vyatka and Novgorod provinces.

Several publications of local researchers (Bonfeld, Golikova, etc.) about the exiled Poles in Vologda from the Kingdom of Poland have been made: about high-ranking commanders of the November uprising, about exiles after Konarsky case and more than 80 participants of the January uprising. On the basis of archival data, episodes of everyday life, biographical data, generalizations are studied. The topic remains relevant for research in the following areas: detailed analysis of biographies, publication of archival sources, study of personal sources: memories of exiles and local residents. 


\section{Anton Liutynski}

\section{POLACY ZESŁAŃCY W GUBERNI WOLOGODZKIEJ W XIX WIEKU: ROSYJSKA HISTORIOGRAFIA I PERSPEKTYWY BADACZE}

Gubernia wołogodzka, region Imperium Rosyjskiego (w latach 1796-1917), był wykorzystywany przez rząd carski w XIX - początkach XX wieku, jako miejsce zsyłek politycznych. Pewna liczba uczestników ruchu rewolucyjnego w Królestwie Polskim w XIX wieku została zesłana na tę prowincję.

Rosyjska historiografia polskich zesłańców odnosi się głównie do regionów syberyjskich, gdzie wygnańców było znacznie więcej. Istnieją interesujące i szczegółowe opracowania dotyczące polskich zesłańców w sąsiednich guberniach archangielska, wiatska i nowogrodzka.

O zesłanych do Wołogdy uczestnikach powstań w Królestwie Polskim powstało kilku wydawnictw lokalnych naukowców (Бонфельд, Голикова и др.): о wysokiej rangi dowódcach wojskowych powstania listopadowego, o zesłańcach konspiracji Konarskiego i o ponad 80 uczestnikach powstania styczniowego. Na podstawie danych archiwalnych badane są epizody z życia codziennego, dane biograficzne, uogólnienia. Tematami istotnymi badawczo pozostają następujące obszary: szczegółowa analiza biografii, publikacja źródeł archiwalnych, badanie źródeł osobowych: wspomnienia zesłańców i mieszkańców.

Słowa kluczowe: wołogodzka gubernia, Polacy zesłańcy, rosyjska historiografia, perspektywy badawcze

Keywords: Vologda province, Polish exile, Russian historiography, research perspectives

\section{BIBLIOGRAFIA}

Алекссева М.А., Сравнительньий анализ положения польских ссыльных в Вологодской и Новгородской губерниях // К 150-летию Январского восстания в Польше..., Великий Новгород 2013.

Береговая Е.П., Польская политическая ссылка в Енисейской губернии во второй половине XIX-начале $X X$ вв.: диссертация... кандидата исторических наук, Красноярск 2007.

Бонфельд М.Ш., Странники поневоле // Вологда: Краеведческий альманах. Вып. 4. - Вологда: “Легия" 2003.

Бонфельд М.Ш., Польская культурная среда в Вологде середины ХІХ века // Поляки и русские: взаимопонимание и взаимонепонимание / Рос. гос. гуманитар. ун-т, Рос. акад. наук, Ин-т славяноведения, Польский ин-т при посольстве РП в Москве, 2000.

Гапоненко В.В., Семенов Е.В., Польские политические ссыльные в хозяйственной и культурной жизни Забайкалья в первой половине XIX в., Улан-Удэ 2006.

Голикова Н.И., Польские ссыльные в Вологодской губернии в 60-е годы ХІХ века // Историческое краеведение и архивы. - Вологда. - Вып. 10, 2004.

Голикова Н.И., Участники польского восстания 1863-1864 г2. в вологодской ссылке // Власть и общество на Европейском Севере России: исторический опыт и современность / Федер. служба исполнения наказаний, Вологод. ин-т права и экономики, Вологод. гос. пед. ун-т, Сев. отд-ние Центра воен. истории России ИРИ РАН, Совет кафедр и секций истории вузов Вологод. обл. Вологда 2010.

Даен М.Е., О польской ориентации в вологодском искусстве ХІХ века // Археография и источниковедение истории Европейского Севера РСФСР.Ч.2, 1989. 
Жарова А.С. Возникновение и развитие польской общины в Курганском уезде Тобольской губернии во второй половине $X I X$ - начале $X X$ в.: автореферат дис... кандидата исторических наук, Челябинск 2015.

К 150-летию Январского восстания в Польше: Польские ссыльные в Новгородской губернии / отв.редактор Б.Н.Ковалев, Великий Новгород 2013.

Кононова Л.П., Ссылка участников польского восстания 1863-1864 годов: По материалам Архангельской губернии: автореферат дис... кандидата исторических наук, Архангельск 2004.

Латыпова В.В. Поляки на Южном Урале (XVII - начало XX вв.): автореферат дис... кандидата исторических наук, Санкт-Петербург 1996.

Макарова Е.А., Сравнительный анализ польских ссыльных в Вологодской и Новгородской губернии // К 150-летию Январского восстания в Польше: Польские ссыльные в Новгородской губернии / отв. редактор Б.Н. Ковалев, Великий Новгород 2013.

Мулина С.А. Мигранты поневоле: адаптация ссыльных участников польского восстания 1863 года в Западной Сибири; отв. ред. проф. А.В. Ремнев. Санкт-Петербург: Алетейя 2012.

Островский Л.К., Поляки в Западной Сибири в конще XIX-первой четверти XX века: диссертация... доктора исторических наук, Новосибирск 2014.

Пичугина В.В., Польская интеллигенция в общественно-политической жизни Поволжья и Приуралья (в XIX веке): автореферат дисс.... канд. ист. Наук, Казань 2000.

Подлевских Л.Г., Польская политическая ссылка в Российской провинции в 1860-начале 1880-х г2.: На материалах Вятской губернии: автореферат дис... кандидата исторических наук, Ижевск 2004.

Польская политическая ссылка в России XIX-XX веков региональные аспекты / Сборник статей, Казань 1998; Поляки в России: XVII-ХХ вв., Краснодар 2003.

Русско-польские револючионные связи: В 2-х т. Т. 2. Восстание 1863 г.: Материаль и документы. М.: Изд-во АН СССР, 1963.

Селицкий А. И., Поляки на Кубани: Исторические очерки, Издание Кубан. гос. ун-та. Краснодар 2008.

Терехин А.А., Ссылка в Пермской губернии в XIX в. Диссертация на соискание ученой степени кандидата исторических наук. Пермь 2003.

Тираспольский Г.И., Ссыльныле поляки в Усть-Сысольске 1860-х г2. // Родники Пармы.Республиканский научно-краеведческий альманах. Вып. 5, Сыктывкар 2000.

Участники Январского восстания в ссылке в Новгородской губернии: сборник документов, Великий Новгород 2015.

Цифанова И.В., Польские переселенцы на Северном Кавказе в ХІХ веке: Особенности процесса адаптаuии: автореферат дис... кандидата исторических наук, Ставрополь 2005. 